\title{
Aquém das miragens: a negatividade no âmago da experiência
}

Rita Paiva

Professora de filosofia da EFLCH, Universidade Federal de São Paulo 



\section{As miragens da lógica e o vacilo da vontade}

Comumente, a filosofia bergsoniana é interpretada sob o signo da alegria e da positividade. Aura que encontra lastro por toda a obra do filósofo, mais particularmente nos textos em que a angústia e a inquietação com o vazio são concebidas como miragens da inteligência. No último capítulo de A evolução criadora, a ideia do nada, da ausência, da desordem atuam como pressupostos necessários quando "a vida olha para fora" e se coaduna com a urgência de viver e sobreviver. Ao visar seus objetivos, a inteligência projeta uma ausência sobre a materialidade que se oferece ao seu agir; ela passa, assim, a perseguir a expectativa de preencher essa falta e de sanar o seu carecimento. Nesse sentido, o filósofo não se furta a sublinhar que essas imagens são relativas às urgências utilitárias do agente e por elas secundadas. Em O possível e o real, texto de 1920, no qual Bergson retoma esses argumentos, lemos: “(...) importa particularmente a nossa indústria que nosso pensamento saiba atrasar-se em relação à realidade e permanecer preso, quando necessário, àquilo que era ou àquilo que poderia ser, ao invés de ser acaparado por aquilo que é" (Bergson 2006, p. 111). Destarte, o intelecto procede necessariamente em consonância com uma trajetória que vai do vazio ao pleno, da ausência à presença, do irreal ao real; seu intuito é sempre o de inventar o que ainda não existe ou alcançar algo que elimine a vacuidade em que ele se encontra. A suposição prévia do vazio e da falta é crucial quando agimos; essas representações despertam o anseio de superação e estimulam a ação. Daí decorre que uma ausência e uma falta estejam inevitavelmente inscritas em nossa vida prática.

Com efeito, a ideia de nada adquire significação e de fato revela sua legitimidade quando nos circunscrevemos ao campo da ação e da vocação fabricadora do homem. A despeito disso, não há como nos esquivarmos do real e do pleno; estamos e vivemos invariavelmente nele. À imagem da ausência subjaz, na verdade, a decepção de uma inteligência que encontra no lugar do objeto, 
da ordem ou do acontecimento esperado, uma realidade outra. $\mathrm{O}$ texto elucida-nos:

(...) a irrealidade da qual se trata aqui é puramente relativa à direção na qual se engajou nossa atenção, pois estamos imersos em realidades e delas não podemos sair; só que, quando a realidade presente não é aquela que procurávamos, falamos da ausência da segunda ali onde constamos a presença da primeira. Exprimimos assim o que temos em função do que gostaríamos de obter. Nada mais legítimo, no território da ação (Bergson 2005, p. 296).

A tese defendida por Bergson é veemente: não há o vazio absoluto ou a ausência em si. Se algo for suprimido uma substituição efetiva-se.

Não obstante, ao enveredar pelas trilhas da especulação e das questões concernentes ao ser, a inteligência transpõe para essa esfera os mesmos esquematismos que regem o agir humano. Mas, para além do vazio relativo que pauta nossas ações, o vazio que se configura no campo especulativo adquire as dimensões do absoluto. Afloram assim as terríveis e insolúveis angústias da metafísica e os equívocos mais contundentes do entendimento humano. Advém daí, sustenta Bergson, a crença de que o único ser sólido o suficiente para perseverar sobre a ausência ou a irrealidade seria aquele que, em sua absoluta abstração, permaneceria incólume ante as alterações sofridas pelas realidades físicas e psicológicas. Postula-se, consequentemente, a necessária coincidência entre o ser e um princípio lógico, do qual se deriva o sentido da existência em sua completude. Deste modo, descortina-se o caminho do absoluto eterno e imutável, o qual permanece incólume aos assédios dessas imagens negativas, com as quais o homem não se defronta sem que seja assaltado pelo desejo desesperado de superá-las. A tradição metafísica, ao vislumbrar o nada como o alicerce do ser, obstina-se em situá-lo para além de toda a realidade que dura, uma vez que a eternidade e a mutabilidade lógica constituem os 
únicos atributos incólumes ante as sinistras ameaças do nada, da ausência ou do caos. Afinal, “(...) a natureza de uma existência puramente lógica é tal que parece bastar-se a si própria e pôr-se pelo simples efeito da força imanente à verdade" (Bergson 2005, p. 300). No entanto, o ser que assim se erige coincide com uma representação simbólica e igualmente fantasmagórica.

Outra a orientação da filosofia bergsoniana. Sob esse registro, enquanto realidade plena e mutante, enquanto temporalidade e duração, o ser se traduz em experiência, jamais em abstração. Quando o nada, essa "pseudo-ideia", revela-se como pressuposto necessário para o encontro do ser, a metafísica se desvia categoricamente da duração, do absoluto livre, temporal e contínuo e envereda por especulações angustiantes acerca da existência e de seus fundamentos. Em A evolução criadora, as asserções bergsonianas aludem à realidade com a qual nos defrontaríamos uma vez que lográssemos o desvio desta representação:

Se pudéssemos estabelecer que a ideia de nada, no sentido em que a tomamos quando a opomos à de existência, é uma pseudo-ideia, os problemas que levanta em torno de si tornar-se-iam pseudoproblemas. A hipótese de um absoluto que agiria livremente, que duraria eminentemente nada mais teria de chocante. O caminho estaria aberto para uma filosofia mais próxima da intuição que não pediria mais os mesmos sacrifícios ao senso comum (Id., Ibid. 2005, p. 301).

Com efeito, a experiência da intuição, que nos faculta a visão do espírito pelo espírito, desviando-nos das vertigens ilusórias da negatividade, exigirá de nós uma inimaginável diligência, um esforço visceral da vontade para inverter a direção habitual e prática do pensar, para superar um aspecto estruturante da condição humana, promovendo a inserção no movimento vital.

Numa breve passagem de $\mathrm{O}$ pensamento e o movente, ao interrogar os caminhos tangíveis pelos quais o pensamento poderia se desviar dos pressupostos negativos - e portanto fictícios - instaurados pelo intelecto, Bergson enfatiza o caráter imprescindível 
desse esforço que conduzirá a uma comunhão com o dinamismo criador do elã. Nessas linhas, esse processo que alarga a percepção e inebria a inteligência é pensado como uma dilatação da vontade. Ou seja, o empenho em se esquivar das searas em que o pensamento humano comumente opera, requer primeiramente um embate com a vocação essencial da inteligência, que encontra na ação prática o seu habitat natural. Para tanto, torna-se crucial uma torção do querer sobre si mesmo, a qual não apenas nos desvendará o caráter fantasmático de toda falta, mas viabilizará o contato com a dimensão movente e criadora da vida. Ainda que, por conta dos limites de nossa condição, nele não possamos permanecer, esse contato bastará para que vislumbremos o absoluto no qual estamos insertos e para que compreendamos a natureza última das ilusões negativas.

Ao debruçar-se sobre esses argumentos, Bento Prado considera que a filosofia bergsoniana se erige sob o signo da alegria. São falsos os dilemas metafísicos que a angústia proveniente dessas imagens ilusórias engendra; é equívoca a vacuidade sobre a qual o existir parece ancorar-se. Daí deriva que as imagens da negatividade, enquanto miragens que são, atualizariam não apenas os equívocos que se incrustaram no pensamento filosófico desde seus primórdios, mas também as fontes das mais tenebrosas inquietações que irrompem na vida humana, tais como a perplexidade ante o caos, o sentimento do vazio e da ausência de alicerces para a existência. Sob essa perspectiva, o esforço necessário para ultrapassar a razoabilidade da inteligência, a grande autora dessas ilusões que não encontram respaldo no âmbito de uma metafísica positiva, poderá conduzir à superação da condição humana, descortinando, enfim, a experiência da duração, enquanto sucessão de realidades plenas. Não há, na ordem do ser, lugar para a falta, para a negativo ou para os dilaceramentos que deles decorrem. Perspectiva que se inscreve igualmente na leitura de Jankélévitch: "Na plenitude perfeitamente presente, sempre viva e particular do devir não há lugar para os ídolos da metafísica infeliz: o nada, 
a negação, o acaso, o possível, o vazio, o mal (...)" (Jankélévitch 1959, p. 246). A alegria que assim aflora advém da coincidência com o tempo da mudança, da fusão com o processo vital e criador. Por outro lado, Bento Prado observa com acuidade:

Pensar em duração é identificar-se com a temporalidade do próprio surgimento do objeto enquanto objeto. E desta perspectiva 'divina' dissipam-se as angústias ligadas à condição humana que, no nível da consciência filosófica, assume a forma de uma interrogação pelo fundamento e pela origem do próprio ser (Prado Jr. 1989, p. 37).

Conquanto a retomada da crítica à negatividade em $\mathrm{O}$ pensamento e o movente pareça, de pronto, limitar-se a uma ratificação da crítica tecida em A evolução criadora, ela instaura uma sutil diferença, que não chega a contradizer as reflexões tecidas em 1907, mas acrescenta a elas algo de inaudito. Aspecto que se destaca na análise arguta de Camille Riquier, segundo a qual o texto de $\mathrm{O}$ pensamento e o movente, ao retomar tardiamente as questões problematizadas no terceiro livro bergsoniano, introduz efetivamente uma novidade. De fato, nesse segundo momento da crítica, o advento das ficções negativas da inteligência - ou dos fantasmas de problemas - já não figuram apenas como imagens decorrentes da transposição dos esquemas da prática humana para o pensamento especulativo. Agora, como aponta o comentador, Bergson sustenta que a suposição do vazio ou da falta, bem como a angústia que deles decorre não são produtos apenas de um excesso de lógica, mas, sobretudo, de um pensamento que, em virtude de sua debilidade, evoca possibilidades sombrias e mórbidas no que concerne aos resultados de suas ações e ao destino de sua existência. Como entender essa debilidade? Atentemos aos dizeres bergsonianos tal como se apresentam em O pensamento e o movente, de 1934:

(...) sentimos que uma vontade ou um pensamento divinamente criador é por demais pleno de si mesmo, em sua imensidão de realidade, para 
que a ideia de uma falta de ordem ou de uma falta de ser possa sequer lhe ocorrer. Representar-se a possibilidade da desordem absoluta, com mais forte razão a possibilidade do nada, seria, para um tal pensamento, o mesmo que se ele se dissesse que ele não poderia ter existido de modo algum e isso seria uma fraqueza incompatível com sua natureza, que é força. Quanto mais nos voltamos para ele, tanto mais as dúvidas que atormentam o homem normal e são nos parecem anormais e mórbidas (Bergson 2006, p. 69). ${ }^{1}$

$\mathrm{O}$ texto desconcerta. Bergson efetivamente sugere que as miragens das ideias, os pensamento negativos afloram - ou só poderiam aflorar - em virtude de uma fraqueza que não encontra respaldo num pensamento criador, leia-se, perpassado pelo ímpeto da vida. O que assim se configura é um declínio da vontade, um rebaixamento de sua potência. ${ }^{2}$ Decerto, um real que nos decepciona, suscita em nós a estratégia geradora das imagens negativas, as quais atuam como estímulos para a ação; tal o registro prevalente em A evolução criadora. Não obstante, ao sugerir que essas imagens não se limitam à condição de aspecto constitutivo da pragmática humana, e ao insinuar que elas podem derivar de uma fraqueza do pensar, o filósofo nos desvela uma perspectiva outra. Bergson passa a considerar que a decepção ante o real pode reverberar sobre o querer do indivíduo, exaurindo seu vigor, de sorte que as ações posteriores a essa frustração comportem apenas uma "meia vontade". São, pois, atos fragilizados na sua vitalidade e na sua capacidade de perseverar que se seguirão ao mal-estar ante um real que frustra expectativas. Em suma, a partir dessas considerações, vemos que as imagens negativas que assediam a

1 Grifo nosso.

2 Nesta filosofia, a noção de vontade atravessa a obra e distingue-se de uma faculdade psicológica isolada ou que encontra lastro na razão. Esse conceito relaciona-se, pois, com o impulso que atravessa a alma permitindo que o conjunto da memória inscreva-se no presente e se lance em direção ao futuro. Ela pode ser concebida, pois, como um estado de tensão, o qual, ao sustentar a contração dos tempos e ao viabilizar a inserção da memória contraída no presente, propicia a atuação humana no mundo e a criação. A esse respeito, ver François 2008, p. $4^{8 .}$ 
especulação já não decorrem apenas do modo de agir habitual da inteligência, a partir do qual avaliamos o real com critérios e demandas que o excedem. Elas já não constituem apenas uma transposição desse modus operandi para o universo especulativo, mas revelam também uma certa insuficiência da vontade que chancela nossa condição. Fragilidade que finda por obstruir o impulso que nos perpassa.

Eis o ponto crucial para nossa discussão: doravante, essas representações atestam um declínio do ímpeto do elã que move a totalidade do nosso passado em direção ao futuro, e que é responsável pela inserção positiva de nossa ação no mundo circundante. O pensamento negativo se configura, insiste o filósofo da duração, como resultante de um "deficit de querer". A nossa condição de ser agente no mundo encontra-se, pois, comprometida. É com elegância que o comentador sublinha o despontar da negatividade na filosofia da alegria e da positividade:

O nada não é mais inicialmente uma categoria prática que impregna a reflexão e impede a verdadeira especulação, mas reflete, sobre o plano teórico, uma fraqueza da vida prática. É expressão de nossa decepção face a uma realidade que contradita nosso esforço ou nossa atenção, freia nosso elã em direção ao futuro e lesa ao mesmo tempo nosso poder de agir (Riquier 2009, p. 419).

Notemos, entretanto, que, em $O$ pensamento e o movente, Bergson refere-se com certa brevidade a este vacilo do elã na interioridade humana.

\section{A dimensão vital da negatividade e a doença da espécie}

Uma fundamentação mais vertical dessa problemática será encontrada em As duas fontes da moral e da religião, texto que, aliás, antecede em dois anos o texto de 1934. Nesta obra, as imagens da negatividade adquirem claramente um teor bastante distinto 
daquele postulado no último capítulo de A evolução criadora. Doravante, as imagens do nada e do vazio serão delineadas como resultado da própria ação vital, uma vez que se revelam como imanentes ao mais complexo resultado da vida. Mais precisamente, se as imagens negativas que afloram habitualmente na mente do homem normal soam como mórbidas e culminam no enfraquecimento do espírito, como sustenta Bergson em sua segunda crítica às fantasmagorias da inteligência, torna-se legítimo inferir que a inteligência traz em si os germes de um niilismo que já nada têm a ver com fantasmagorias engendradas por necessidades pragmáticas. Agora, as imagens da negação respaldam-se na experiência que corta a carne e que não se deixa negligenciar. Eis o que nos revela o último livro.

Inequivocamente, não aludimos aqui aos distúrbios da personalidade que poderiam comprometer a atenção que a inteligência deve prestar à vida, ofuscando os propósitos de ação no mundo, sobre os quais Bergson se debruçou em Matéria e memória. Nesse caso, certos desequilíbrios, normalmente contidos pelo esforço de atenção, irrompem justamente quando o intelecto, distraído das demandas mundanas, perde o controle seletor das imagens que o assediam. O que nos torna a todos vulneráveis aos desequilíbrios mentais e aos assédios da loucura. ${ }^{3}$ Outra a direção

3 Em Matéria e memória, Bergson atribuirá à inteligência o papel de ajustar o encontro entre o movimento da vida em nós, ou seja, do tempo e do espírito, e as estruturas sensório motoras, de modo que o passado se inscreva no presente e as perspectivas de ação futura se descortinem. Processo em que a seleção das imagens mnemônicas compatíveis com as demandas utilitárias da ação ocorre em simultaneidade com uma contenção daquelas que ultrapassam tais interpelações. Logo, caberá à consciência reflexiva a tarefa de dirigir a atenção à vida, impedindo a preponderância dos estados de dispersão mental. Considera o filósofo: "O que caracteriza o homem de ação é a prontidão com que convoca em auxílio de uma situação dada todas as lembranças a ela relacionadas; mas é também a barreira insuperável que encontramos nele, ao se apresentarem no limiar da consciência, as lembranças inúteis ou indiferentes" (Bergson 1990, p.126). A perda desse controle opera a proliferação dos distúrbios mentais, aos quais estaríamos todos propensos. Em Bergson, de fato, é tênue e tenso o limite que nos separa da anormalidade; basta que a tensão exercida pela inteligência vacile para que a riqueza da vida mental transborde, ofuscando a lógica e a clareza pelas quais pauta-se a consciência reflexa. Daí decorre que entre o normal e o patológico 
seguida pelo filósofo em As duas fontes. Aqui, as representações negativas sinalizam disposições oscilantes, angústias que dimanam com virulência no cerne da própria razão, e configuram-se, simultaneamente, como uma contrapartida da abertura que singulariza o ser inteligente ante outras espécies. Noutros termos, em virtude da indeterminação com que a natureza dotara os seres pensantes, a inteligência pode desviar-se da pura conformidade com as demandas objetivas, de sorte que o pensamento se volte para fins não necessariamente instrumentais. Mas nesse privilégio reside também a fresta pela qual reflexões inquietantes, perplexas com sua própria condição e fonte de grande sofrimento advêm, debilitando a aptidão humana para responder às solicitações práticas da vida, visto que suscitam o desinteresse e comprometem a disposição necessária para atuar no presente e antecipar o futuro.

A este ponto acrescenta-se um fato cuja relevância é determinante para a discussão que vimos tecendo. É crucial enfatizar que, além de comportar uma flexibilidade que a conduz a interrogações e vacilações que fragilizam sua capacidade de ação, a inteligência, ao viabilizar a sobrevivência, garantindo a ação sobre a matéria, apreende a vida no universo das suas representações espacializadas e estáticas, as quais suprimem o dinamismo do real, recortando do movimento contínuo o que interessa aos seus intentos pragmáticos. Imersa nesse habitat, a inteligência não pode jamais compreender a vida, coincidir com o seu movimento, uma vez que se limita a apreendê-la do exterior. Enquanto criação vital, é no processo de inversão do elã, o qual origina simultaneamente a materialidade e o pensamento racional, que o intelecto separa-se do processo criador, abrindo as margens para o sofrimento ou para uma negatividade efetiva. Essa cisão, por um lado, distancia o pensamento da vida, instaura a via das represen- 
tações em geral e das representações deprimentes, em particular; por outro, acena com a possibilidade de que as desmedidas do intelecto elevem a catástrofe à condição de seu horizonte mais certeiro, comprometendo, talvez, o futuro da humanidade. Daí decorre que uma propensão ao negativo figure como algo cravado na condição humana; uma experiência, pois. F. Worms aponta: “(...) a filosofia bergsoniana da vida, se não seu vitalismo, permite explicar e mesmo engendrar o niilismo, e não apenas a ideia de nada, em toda sua gravidade metafísica e histórica"4

É nesse sentido que, segundo David Lapoujade, a preocupação com o l'attachement à la vie se constituirá como a pedra angular do último livro bergsoniano (Lapoujade 2010, p. 77). Isto porque os sofrimentos oriundos da cisão originária, bem como a tenebrosa perspectiva mobilizada por certos desconcertos íntimos, ameaçarão tanto a existência coletiva quanto a individual; angústias que se erigem em forte contradição com a marcha do ímpeto vital e que fragilizam a vontade humana de investir na vida. Um olhar soturno irrompe, pois, na filosofia da positividade e da alegria. No cerne destas inquietações encontramos o que Bergson denominará as tendências deprimentes da inteligência. Debrucemo-nos sobre elas.

Nos dois pontos em que, sob a ótica bergsoniana, encontramos os cumes da evolução - os insetos e os homens -, a vida social se apresenta plenamente consumada. Entretanto, uma diferença de pronto se anuncia. Nas sociedades naturais, o indivíduo vive

4 F. Worms manifesta-se a esse respeito com muita propriedade ao afirmar que, em Bergson, encontramos, na verdade, um vitalismo que compreende a negatividade e o niilismo. E são dois os modos pelos quais se opera essa compreensão. Primeiramente, a vida compreende o niilismo porque o explica, enquanto uma necessidade lógica, tal como Bergson argumentou em sua crítica ao nada e aos seus desdobramentos. Por outro lado, o impulso vital inclui o niilismo e suas consequências mais profundas, uma vez que ele se revela uma produção da própria vida: "Reconhecemos, então, que a filosofia bergsoniana da vida, senão seu 'vitalismo', permite explicar e mesmo engendrar o niilismo, e não apenas a ideia de nada, em toda sua gravidade metafísica e histórica" (Worms 2009, p. 17). 
substancialmente em função de uma regularidade fixa e instintiva; no mundo humano, a ordem social é constituída por seres inteligentes, dotados de liberdade. Antes mesmo da discussão vertical que tecerá em seu último livro, em A Consciência e a vida, Bergson alude à tensão fundamental que se inscreve no cerne de toda organização humana: "A sociedade, que é o compartilhamento das energias individuais, beneficia-se com os esforços de todos e torna mais fácil o esforço de cada um. Ela só pode subsistir se subordinar o indivíduo, só pode progredir se deixá-lo agir: exigências opostas, que seria preciso reconciliar" (Bergson 2009, p. 25). Entrevemos, assim, um necessário paradoxo entre as vontades livres e os interesses da vida coletiva, o qual inscreverá fortemente na existência humana.

No primeiro capítulo de As duas fontes da moral e da religião, o filósofo alude à forte inclinação que viceja em cada indivíduo para privilegiar intentos e searas que concernem a deliberações exclusivamente suas, em detrimento do todo em que ele se insere e sem o qual dificilmente sobreviveria sozinho. Decerto, a generalização de comportamentos desse tipo ameaça a necessária coesão social, uma vez que eles negligenciam ostensivamente as consequências de atos individuais sobre outrem. Ademais, à medida que se pauta por tais condutas, o indivíduo põe também a sua vida em risco, uma vez que é o vínculo com a sociedade que fornece o norte para as suas ações particulares. O fato é que, por um lado, a sociabilidade nos é imprescindível; por outro, em gradações diversas, resistimos a ela. Insiste o autor: "O homem (...) não pode refletir sobre o que a natureza lhe pede, na medida em que esta fez dele um ser sociável, sem se dizer que muitas vezes seria benefício, se descurasse os outros e cuidasse apenas de si mesmo" (Bergson 2009, p. 174). Bergson identifica a tensão imanente a toda vida civilizada; sua reflexão enfatiza a potência desintegradora que viceja em nós e que ameaça os laços sociais como um traço constitutivo de seres dotados de vontade livre.

Essa ânsia de dissidência que perpassa a inteligência constitui 
o primeiro aspecto sobre o qual o autor se debruça para problematizar a emergência, no âmbito da própria inteligência, de representações deletérias que ameaçam obstaculizar as sendas do elã. Afinal, considerando-se que a ordem social constitui quesito sine qua non para a conservação da espécie - e, portanto, à manutenção da vida humana -, essa propensão egoística não constituiria, em última instância, um obstáculo ao avanço do elã? Ademais, esta primeira sombra lançada pela inteligência sobre o ímpeto da vida - a vocação dissolvente - é reforçada por uma inclinação à onipotência que assedia o intelecto e que lhe é igualmente intrínseca, impedindo-o de avaliar claramente as dimensões catastróficas de seus anseios. Mais claramente, ao lançar-se em ações que viabilizem seus intentos e projetos, movidos pelo anelo de se singularizar ou imbuídos de grande entusiasmo com eles mesmos e com suas potencialidades, os seres inteligentes terminam por negligenciar os desdobramentos nefastos de suas escolhas e de seus desejos, extrapolando os parâmetros dentro dos quais se devem mover. O que se ausenta, assim, são os índices necessários de sensatez que possam se contrapor a uma razão deslumbrada consigo mesma. Nesse caso, tal como no seu desejo de emancipação em relação ao todo, o dom do intelecto torna-se uma força de desintegração incrivelmente potente. Destarte, uma ambígua conotação advém. Por um lado, sem dúvida, a inteligência constitui a chave que permite à sociedade humana progredir e transmudar-se, incrementando indefinidamente seus níveis de complexidade, garantindo a continuidade à marcha do elã; por outro, ela atua como signo de ruptura e espectro de destruição, ameaçando a continuidade da vida. Não obstante, sua vocação negativa não se atualiza unicamente em seus impulsos egoísticos ou nos desvarios que a impedem de vislumbrar o atroz que nela pulsa.

Um desvanecimento da vontade e um sentimento de impotência para seguir adiante e persistir na vida podem irromper no íntimo dos seres inteligentes em virtude da ciência acerca da vulnerabilidade de sua condição. Sem dúvida, o homem é o úni- 
co ser lúcido acerca do destino que sela sua condição. A generalização do sentimento decorrente dessa clareza pode comprometer o equilíbrio social, à medida que mina as razões que mantêm o homem ligado à vida. Como sustenta Bergson, a atuação do elã na natureza deu-se de modo que as espécies vivas em geral cumprissem sua existência como se a morte não as assediasse, a despeito dos mecanismos de defesa que desenvolvem para as situações de perigo. No que tange aos seres humanos, o advento da inteligência e da representação evidencia dolorosamente que a existência humana não permanece incólume às leis fundamentais da vida. Consequentemente, deparamo-nos com um outro paradoxo derivado do próprio movimento vital. A criação de seres inteligentes deflagra alternativas inusitadas para a perpetuação do movimento criador, mas se um homem olha o vazio e sente que não há solidez sobre a qual possa ancorar sua existência, como evitar que essa lucidez reverbere sobre sua vontade e lance seu espírito em águas de puro desalento? Como frear a produção de pensamentos sombrios que esgotem suas energias e esfacelem seu desejo de prosseguir no impulso que o lança em direção ao futuro? As representações que assim advêm deflagram sentimentos deprimentes e pensamentos que amortecem, no homem, o impulso que deve nortear o seu agir. A certeza de que a morte é inexorável constitui, efetivamente, a representação que mais fortemente pode obstaculizar o avanço do impulso vital num ser inteligente. O filósofo argumenta: “(...) a certeza de morrer, surgindo com a reflexão num mundo de seres vivos feitos para pensar apenas em viver, contraria a intenção da natureza. Esta vai tropeçar no obstáculo que lhe aconteceu de colocar no seu próprio caminho" (Bergson 2005, p. 117). Explicita-se, destarte, um tipo de desequilíbrio que irrompe no âmago do pensar, e que culmina numa fragilização da vontade de viver.

Não obstante, Bergson debruça-se ainda sobre outras maneiras pelas quais a negatividade dimana no cerne da consciência humana: "O homem é o único animal cuja ação se mostra pouco 
segura, que hesita e tateia, que forma projetos com a esperança de ser bem sucedido e o receio de falhar" (Bergson, p.174). Logo, é prerrogativa humana tecer planos a longo prazo, avaliando a amplitude de seu domínio sobre o desdobrar dos acontecimentos. Na lida habitual dos dias, na administração dos problemas, sejam eles banais ou não, acidentes de toda ordem podem advir, escapando ao planejamento e às expectativas nutridas pelo agente. Quanto maior o amor que o intelecto nutre pelo perigo, mais o insucesso emerge como um horizonte factível; explicitando que o indivíduo está sujeito a forças imponderáveis, sejam elas sociais ou naturais, as quais podem, inclusive, esmagá-lo. Essa margem de imprevisto que cerca as ações humanas, em última instância, contradita o procedimento natural da inteligência. Esta pauta-se ordinariamente por uma operacionalidade mecânica, segundo a qual toda causa tem por certo um efeito previsível e plenamente calculável: "Mas é da essência da inteligência combinar meios em vista de um fim longínquo, e empreender o que se não sente inteiramente senhora de realizar" (Id., Ibid. 2005, p. 125). Essa inclinação estende-se, no caso das culturas tecnicamente mais desenvolvidas, as suas construções teóricas, visto que o intelecto nutre a expectativa de que a ampliação universal desse modus operandi suprima em grande parte a imprevisibilidade inscrita nos acontecimentos. Ela também prevaleceria nas explicações prevalecentes entre as culturas não modernas, se fosse possível formalizá-la. Bergson, novamente: "Se a ciência fornecesse ao não civilizado um dispositivo que lhe garantisse matematicamente acertar o alvo, seria à causalidade mecânica que ele se ateria” (Id., Ibid.). Logo, é insuportável ao homem - moderno ou não - supor que outras dimensões da existência ou mesmo aquelas ligadas a sua vivência afetiva escapem aos registros explicativos que lhes são habituais.

Ademais, lembra Bergson, o agir humano é estimulado pelo sopro vital e resulta de um movimento impulsivo que inscreve toda a memória no presente delineando assim o futuro; não há 
nele tolerância para o acidente ou para o imprevisto. Pontos fixos e referências sólidas, capazes de orientar a ação humana no mundo constituem, pois, um carecimento primordial para um ser que tem por destino natural a ação sobre a matéria. Entretanto, ainda que o empenho em construir explicações teóricas ou não estimulem o trabalho da inteligência e pairem como referências ideais, elas não necessariamente fornecem garantias a contento.Um mundo destituído de intenções ou de determinações absolutas é também isento de sentido, perpassado pelo nada. Daí que a ausência desses elementos possa culminar em pensamentos atemorizantes, que pulverizam seja a confiança, seja a força necessária para persistir. Consequentemente, com a insegurança que todo homem tem acerca dos desdobramentos de seus atos, das garantias concernentes aos sonhos que persegue, um desequilíbrio talvez tão vertiginoso quanto aquele operado pela consciência da mortalidade pode advir. Como as tendências egoísticas, como o entusiasmo onipotente e a depressão da vontade ante a condição mortal, o vácuo entre o ato e sua finalidade constitui uma campo fértil para que o pensamento negativo prolifere.

Em suma, são essas as vias exploradas pelo filósofo para deslindar o modo pelo qual a morbidez e a anomalia se aninham na mente de um homem normal. Imanentes à normalidade da inteligência, o vislumbre da ausência e da falta - a experiência do nada, portanto - suscita um desequilíbrio que ameaça corroer os laços que mantêm o homem ligado à vida, obstaculizando perigosamente a continuidade do movimento criador. Em última instância, esses tormentos angustiantes constituem, na pertinente expressão de D. Lapoujade, uma forma particular de "depressão biológica”, uma vez que, para além da experiência individual, concernem à espécie em sua totalidade. Com ela, uma vertiginosa ameaça à potência do querer humano adquire tangibilidade, o que ocorre justamente com o ser que demonstrara coincidir seja com o ponto culminante da evolução, seja com a sua "fina- 
lidade", tese que Bergson sustentara não sem reticências em A evolução criadora. ${ }^{5}$

Em As duas fontes, veremos que, se a interioridade humana constitui, na bela imagem de Gouhier, o teatro em que o ímpeto criador do elã perpetua suas ações, é também por essa via - ou seja a do humano - que a negatividade se manifestará em grau máximo (Gouhier 1961, p. 98). Numa palavra, a seara na qual o elã triunfa sobre todos os obstáculos será também aquela pela qual o sofrimento, o mal e a visão do vazio advêm, sem que se confundam com fantasmagorias engendradas por orientações pragmáticas ou desequilíbrios de uma inteligência desatenta. Doravante, urge reconhecer que a interioridade humana na qual o elã se prolonga, não é habitada apenas pelo ímpeto de vida que impulsiona a vontade, mas também por um ensejo negativo e alentecedor, um desejo de não movimento, ou de morte, como o diríamos em instâncias freudianas, de modo que a negatividade já não consiste em representações estranhas ao movimento vital; ela é intrínseca ao homem e é gerada no próprio movimento em que a inteligência advém.

Sob essa perspectiva, explicita-se uma questão primordial: de que modo a espécie poderia superar ou desviar-se dessa negatividade que irrompe em seu âmago, superando a anormalidade que lhe é, por assim dizer, congênita? Como recuperar a coragem

5 Na terceira obra bergsoniana, o movimento vital parece adquirir uma finalidade retrospectiva, como se a vida se tivesse mobilizado para fazer surgir, no seu ápice, este ser por meio do qual ela expandirá sua potência de invenção. Decerto, este ser não traz consigo todas as tendências que a vida enseja em sua história, mas caberá a ele perseguir indefinidamente a realização do movimento vital. O percurso da história cósmica, tal como tecida em A evolução Criadora, adquire, pois, uma finalidade, ainda que permaneça incólume a todo determinismo: "Embora tenha havido outras linhas de evolução ao lado da que conduz ao homem, e apesar do que há de incompleto no próprio homem, podemos dizer, atendo-nos de perto à experiência, que é o homem que é a razão de ser da vida em nosso planeta" (Bergson 2005, p. 288). Inequivocamente, Bergson não estanca sua crítica ao finalismo, mas vislumbra na tessitura da história natural - ou cósmica - uma espécie particular de finalidade isenta de determinação, à luz da qual a vida parece organizar-se em direção àquela que será a sua maior obra. 
necessária para lançar-se no mundo e seguir o impulso em direção ao futuro? A reflexão desenvolvida por Bergson em As duas fontes vem justamente problematizar os caminhos pelos quais as perigosas perturbações engendradas pela inteligência, ou seja, as formas que adquirem sua propensão à negatividade, serão, em alguma medida, contornadas por estratégias engendradas pela própria vida.

\section{A contrapartida vital: sociabilidade, moral, religião}

Ao problematizar a natureza do elã vital, Bergson considera que em sua condição de pura virtualidade, esse impulso traz em si tendências que poderão ou não se atualizar. ${ }^{6}$ A estas tendências múltiplas de diferenciação - como o evidencia Deleuze (1999, p. 76) - são intrínsecas as potencialidades todas do processo criador, sem que se constituam como fontes de determinação. Inversamente, são elas que, associadas ao esforço exigido no embate do impulso vital com a matéria, suscitam a inesgotável e surpreendente variabilidade que se inscreverá nas obras das vida. Bergson, em A evolução criadora: "A vida é tendência, e a essência de uma tendência é de se desenvolver (...), criando, apenas em função de seu crescimento, direções divergentes entre as quais se dividirá seu élan" (Bergson 2005, p. 113). Logo, se o elã consuma o jorro de novidades que advém com a duração, as tendências que nele vicejam justificam igualmente o advento do novo e de existências

6 O elã pode ser compreendido como o princípio interior, dinâmico e imanente a tudo o que vive. Por meio dele, a duração, enquanto fundamento ontológico da existência em geral, e no âmbito da mais radical imprevisibilidade, se expande e o universo advém, com a criação dos seres orgânicos e de tudo o que é vivo. Esta força originária revela-se como um fluxo de consciência geral que é também memória e pode ser compreendido como uma totalidade simples e virtual, à qual são intrínsecas tendências múltiplas de diferenciação. Bergson: "Esse elã, conservando-se nas linhas de evolução pelas quais se reparte, é a causa profunda das variações, pelo menos das que se transmitem regularmente, que se somam, que criam espécies novas" (Bergson 2005, p. 113). Engendram-se, destarte, as vertentes da evolução, as quais, a despeito de certa complementaridade, são divergentes e se desdobram sem cessar em outras linhas. 
inauditas. Nelas, Bergson avistará elementos que permitirão ao impulso vital se contrapor às inusitadas resistências que emergem na interioridade humana, operando, mesmo que não em termos absolutos, a reinstauração do equilíbrio que a doença da inteligência vem desestabilizar. Afinal, um ser que não lograsse desviar-se dessas perspectivas e que se visse completamente dominado por elas, efetivamente mergulharia no inferno da pura negação (Worms 2011, p. 16). Detenhamo-nos, pois, sobre essas tendências que viabilizarão o restabelecimento do equilíbrio avariado por uma inteligência que se depara com o vazio, com o nada, com o sem sentido do existir.

Sem negligenciar o fato de que as sociedades humanas se constituem sob a égide da liberdade, Bergson postula que a organização social é um imperativo vital. A sociabilidade é condição que se impõe a toda espécie vivente, enquanto inserta na ordem natural; nesse aspecto não há frestas. Os agrupamentos humanos não diferem, pois, dos naturais nesse quesito: ambos saem das mãos da natureza. 7 No caso do homem, entretanto, a organização social adquire especificidades que a singularizam profundamente. ${ }^{8}$ Perspectiva que Deleuze reitera: “(...) a sociabilidade [no

7 Florence Caymex, observa que, ao estabelecer a sociedade como resultante de uma intenção da vida, Bergson erige uma teoria social com fortes conotações naturalistas, para a qual os estudos tecidos pelas ciências biológicas conduzem às linhas de fato. Nesse sentido, sustenta a autora, normas e regras contingentes, o arsenal simbólico de uma cultura que são tradicionalmente concebidos como manifestações irredutíveis de realidades antropológicas, passam a ser tomados como resultados de necessidades vitais, o que “(...) aproxima a teoria bergsoniana das formas mais tardias de sociobiologia. As normas culturais adquiridas, quer dizer construídas e transmitidas, ainda que pertençam a uma ordem especificamente humana, não definem uma esfera de racionalidade transcendente, mas necessidades naturais, visto que elas são a expressão de uma exigência de sociabilidade dada ou solicitada pela natureza. Elas são formas concretas delineadas pelo todo da obrigação, a qual constitui um meio pelo qual a natureza realiza a solidariedade entre os seres inteligentes, quer dizer, dotados de vontades livres para garantir a conservação da espécie" (Caymex 2012, p. 322). Notemos, contudo, que uma drástica ruptura com essa perspectiva se operará no decurso da obra, a partir do momento em que o autor alude à possibilidade de que a inteligência coincida com o movimento da vida e que uma moral resultante da invenção humana advenha, de modo que se instaure o divórcio entre a moral e a natureza.

8 Em seu último livro, Bergson contesta as teses sociológicas que vislumbram na pró- 
sentido humano] só pode existir nos seres inteligentes, mas não se funda sobre sua inteligência: a vida social é imanente à inteligência, começa com ela, mas não deriva dela." (Deleuze 1999, p. 89). Para além da psicologia e da sociologia, é sob a perspectiva do movimento criador das espécies, ou seja, do movimento da vida, apreendido em sua dimensão biológica, que, sob as lentes de Bergson, a natureza da sociedade humana mais radicalmente se revela. O filósofo sublinha: “(...) o homem apresenta sempre dois traços essenciais, a inteligência e a sociabilidade. (...) Mas do ponto de vista em que nos situamos, estes caracteres assumem uma significação especial. Inteligência e sociabilidade devem ser ressituadas na evolução geral da vida" (Bergson 2005, p. 106). Desta chancela que impregna a vida social decorre que tanto no mundo natural quanto no mundo humano, a exigência de equilibrar a liberdade com a sujeição dos indivíduos aos parâmetros coletivos constitua quesito imprescindível para que as espécies possam perseverar. Mas, como antes mencionado, no âmbito do puramente natural, o grau de liberdade dos indivíduos subsume-se a padrões de comportamento que se repetem infindavelmente, com graus ínfimos de variabilidade. Entre os homens, de um ponto de vista evolutivo, vislumbramos a concomitância entre o permanente aperfeiçoamento da sociedade e o alargamento crescente da liber-

pria sociedade seja a sua gênese, sejam os fundamentos últimos que organizam e dotam de sentido o comportamento humano:: “(...) para que a sociedade exista, é preciso que o indivíduo contribua com um conjunto de disposições inatas; portanto, a sociedade não se explica por si mesma; deve-se, por conseguinte, procurar por baixo das aquisições sociais, chegar à vida, da qual as sociedades humanas, como de resto a espécie humana, são apenas manifestações" (Bergson 1978, p. 82). Dando continuidade ao método que pautou toda a sua obra e que implica um diálogo com as ciências, no que concerne à moral, a crítica à sociologia visa particularmente as teses durkheimianas. Para esta teoria sociológica há correlações de funcionamento entre a sociedade e os organismos naturais, mas isto não confere uma natureza biológica à sociedade, cuja realidade seria fundamentalmente mental. Em que pese ao filósofo francês reconhecer os méritos durkheimianos, para ele, serão inaceitáveis os postulados segundo os quais a sociedade tem origem em si mesma, a condição humana é essencialmente social, ou que a fonte privilegiada da moral seja social. Tanto a sociedade, quanto a moral por ela formalizada encontram suas âncoras fundamentais na natureza e na vida. 
dade individual, de sorte que a exigência de articulação entre o todo e o particular permaneça igualmente imperativa, mas com graus de complexidade infinitamente maiores.

Nesse viés, seria lícito afirmar que, na latitude de escolha livre em que os seres inteligentes logram exercer sua potência inventiva, o elã instaura tendências que, a despeito da indeterminação a elas intrínsecas, os incitam a criar formas e comportamentos marcados pela regularidade e por certa homogeneidade. Sob essa perspectiva, algo em nossa própria constituição, algo que a vida fixou em nós, enquanto indivíduos livres, sem que tenha nos encerrado numa forma solidificada, e que não se origina somente na ambiência que nos circunda ou nas deliberações inteligentes, clamará pela vida social, pela obediência e pela adequação ao modus vivendi estabelecido. Sem dúvida, a vida social, no sentido humano, ao qual alude Deleuze, não é normatizada pela natureza. Entre os homens, argumenta Bergson, a determinação natural atém-se a postular disposições, fixando apenas a necessidade da regra. As conformações que ela vai adquirir se delinearão na imensa margem de ineditismo e imprevisibilidade. Mas o que não se pode negligenciar é que nela se inscrevem as injunções pertinentes ao movimento vital. $\mathrm{O}$ autor o afirma com veemência: "O homem pode sem dúvida sonhar ou filosofar, mas tem primeiro de viver; é indubitável que nossa estrutura psicológica esteja associada à necessidade de conservar e desenvolver a vida individual e social" (Bergson 2005, p. 99). Assim, seja qual for a conduta prevalente em certa coletividade humana, a despeito da abertura que lhe é intrínseca, ela, primeiramente, se traduzirá em vida social; em seguida, se inscreverá em formas de existir, fundadas na obediência a certas regras e impregnadas em certos hábitos. Esse teria sido o caminho tomado pelo elã vital para coibir as tendências dissolventes da inteligência, garantindo que o mundo humano, enquanto forma resultante do movimento criador da vida e constituído por indivíduos dotados de vontades livres, não se esfacelasse numa atomização indomável. É sob esse registro que encontramos, já 
no início da última obra bergsoniana, a explicitação da primeira tendência do elã a atuar sobre a inteligência e a coibir sua potencialidade negativa: o pendor à sociabilidade que se amalgama com aquele da obediência. Debrucemo-nos sobre esse enlace.

Evocando a reflexão tecida em seu primeiro livro, acerca da subjetividade humana, Bergson salienta que a originalidade da realidade movente e inefável que habita os confins de todos nós coexiste com a dimensão socializada da personalidade. A inserção na vida social e a coexistência com outras subjetividades igualmente exteriorizadas proporcionam ao indivíduo o sentimento de que ele se insere na espessura do real, uma vez que, sob a égide dos elos sociais, a realidade objetiva adquire densidade. Superficialmente, pois, o eu de cada um espelha o outro e a união é selada pela interdependência e pela disciplina. Mas esta superficialidade adquire aqui a conotação de um fundamento: “(...) é na superfície, em seu ponto de inserção no tecido cerrado das outras personalidades exteriorizadas, que nosso eu em geral acha onde se agarrar. Sua solidez está nessa solidariedade" (Bergson 1978, p. 12). A socialização e o sentimento de solidariedade que afloram em nós naturalmente, ao mesmo tempo em que são cultivados pela ambiência, forjam a personalidade moldada pelos preceitos e pelos ideais de um determinado meio. Constitui-se, assim, uma identidade que, uma vez incorporada pelo indivíduo, estabelece os contornos de seu ser social, o qual oferece lastros inequívocos para a sua condição de ser no mundo. Na ausência dessas raízes, o indivíduo submergiria num isolamento que o divorciaria de toda a solidez necessária àqueles que, antes de tudo, devem agir e viver e que só o podem fazer em sociedade.

Mas se as normas e os parâmetros introjetados determinam nosso comportamento no que concerne aos outros, primeiramente, eles nos proporcionam o sentimento de obrigação em relação a nós mesmos. A rigor, são as demandas e as forças sociais em movimento que impelem e incrementam tanto as atividades individuais, quanto o sentimento da subjetividade. Para além dos estí- 
mulos que o indivíduo sofre com sua inserção social, tudo o que o habita, sua memória e sua imaginação, nutrem-se de elementos oriundos da sociedade, mais particularmente da linguagem. Como Bergson mencionara anteriormente, em A Evolução Criadora, a linguagem não apenas viabiliza a comunicação, ela constitui o pressuposto do mundo humano, o qual não poderia existir sem a constituição de uma ordem simbólica, na qual a linguagem configura o pilar mais determinante. Por conseguinte, ainda que isolado, um indivíduo pensaria e o pensamento discursivo não se consumaria sem um eu social condicionado pelos parâmetros da língua. Não há, pois, insiste o autor, vida humana que não se organize sob o espectro da sociabilidade: "Cultivar esse 'eu social' é o essencial de nossa obrigação para com a sociedade. Sem algo dessa sociedade em nós, ela não teria qualquer poder sobre nós; e basta-nos ir até ela para bastarmos a nós mesmos, se a encontramos presentes em nós" (Bergson 2005, p. 12).

A inserção social propicia que cada um se sinta obrigado em relação aos parâmetros de conduta coletivamente estabelecidos, cuja adesão, em sua generalidade, ocorre de modo voluntário. Com efeito, as exigências externas encontram respaldo nas propensões inscritas no âmago de nossa subjetividade, as quais nos incitam a obedecer, por assim dizer, espontaneamente, como se o sentimento de obrigação irrompesse em nós naturalmente, a despeito de coerções quaisquer. O senso de dever orienta nosso comportamento: "Assim compreendido o dever é cumprido quase sempre automaticamente; e a obediência ao dever, se nos ativermos ao caso mais frequente, se definiria como um ir a esmo ou um desleixo" (Id., 1978, p. 16). ${ }^{9}$ Não obstante, ao lado dessa

9 Bergson reconhece que a resistência efetivamente ocorre de modos variados nos indivíduos, mas não é ela que, em última instância, delineia os comportamentos em relação aos deveres. A resistência não prevalece sobre o ajuste tranquilo que torna a obrigação similar a uma inclinação: "O cavaleiro só tem de se deixar levar; ainda assim teve de montar na sela. $\mathrm{O}$ mesmo acontece com o indivíduo em relação à sociedade" (Bergson 1978, p. 7). 
adesão quase espontânea, a ordem social atua coercitivamente sobre os indivíduos, sobretudo nas sociedades em que, à revelia das tendências dominantes, é ampla a margem para a expressão de singularidades e de idiossincrasias - as sociedades modernas, o diria Durkheim. ${ }^{10}$ Logo, por maior que seja a margem de liberdade pertinente aos indivíduos, quando as veleidades se exacerbam e ameaçam os preceitos que respaldam a coesão do todo, uma força pressiona o indivíduo, coagindo-o e induzindo-o a obedecer aos imperativos morais que regem as condutas de seus semelhantes. Fundindo-se num único movimento, as obrigações atuam sobre os sujeitos destoantes, sufocando as inclinações perigosas, de modo que os ditames da ordem prevaleçam. Com ela, a necessidade prepondera sobre a liberdade, e é com a necessidade que a obrigação se coaduna; é a ela que o indivíduo finda por se submeter. ${ }^{11}$

Essa urgência de conformação entre vertentes opostas - a necessidade e a liberdade - permite-nos vislumbrar os imperativos da vida atuando sob a ordem humanamente organizada,

10 Em toda ordem social, mesmo nas sociedades mais complexas, distintas daquelas organizadas de modo mais homogêneo, sustenta o filósofo, o natural se preserva intacto e vivo sob a égide dos elementos adquiridos, os quais, aliás, não são transmitidos hereditariamente e dotam as sociedades de maior grau de diferenciação. Daí que seja viável aludir a algo de essencial, que advém do próprio movimento vital e que é universalmente preservado na conformação de toda e qualquer sociedade: "O natural é hoje o que foi sempre. É verdade que as coisas se passam como se se tivesse transformado, uma vez que o cobre agora todo o adquirido da civilização, moldando a sociedade os indivíduos através da educação que prossegue sem interrupções desde que nascem. Mas basta que uma surpresa brusca paralise estas atividades superficiais, que a luz à qual trabalham se apague por um instante: imediatamente o natural reaparece, como a imutável estrela na noite” (Bergson 2005, p. 140).

11 Bergson chamará "o todo da obrigação" essa tendência que se atualiza na sociedade humana e que coage - ainda que, em geral, de modo imperceptível - os homens a contraírem hábitos, a ligarem-se uns aos outros, a obedecerem à pressão que sobre eles se exerce. A rigor, a edificação de um sistema de regularidades em relação ao qual nos sentimos obrigados - e que nos impelem à obediência - inscreve-se profundamente nos indivíduos e vem ao encontro da necessidade mais crucial de toda comunidade: sobreviver e perseverar. Logo, se a natureza específica que as condutas habituais assumem é algo que está na alçada da inteligência e de sua inventividade, a constituição de tais condutas nada tem de acidental; mas, sustenta Bergson, "liga-se aos fenômenos mais gerais da vida" (Id., Ibid. 2005, p. 39). 
bem como sobre a moralidade por ela constituída, a qual, sob a perspectiva desta filosofia, não se ancora em matrizes racionais. Ainda que se subsumam ao registro da variabilidade, e se manifestem por vias psicológicas e culturais, atestando a emancipação humana em relação à natureza, as obrigações morais, o conjunto dos hábitos que suscitam em nós o sentimento do dever, ocupam, no homem, um lugar similar àquele do instinto. Assim como os seres em geral permanecem ligados a sua espécie à medida que são condicionados a certos tipos de comportamento, ao se sentirem obrigados e ao se conduzirem de acordo com certos preceitos morais - ou hábitos -, os homens se reconhecem insertos numa ordem humana e vivenciam mais fortemente essa identidade. ${ }^{12}$ Bergson não se furta a tecer um paralelo entre a ordem humana e a ordem dos seres vivos em geral, ainda que a associação

12 Ao contestar o intento da filosofia de estabelecer os fundamentos da ordem moral na razão humana, Bergson volta-se particularmente contra a moral kantiana. Sublinha, assim, a incapacidade das deliberações racionais para legislar de modo cabal sobre a nossa vontade. Não há aqui negligência em relação ao papel da lógica na constituição da moral, o qual é importante, ainda que secundário, uma vez que não cabe a ela conduzir à coerência ética. A razão, insiste o autor, pouco logra ante a força das paixões e das tendências egoísticas: “(...) um ser inteligente age sobre si mesmo por intermédio da inteligência. Mas, pelo fato de ser por vias racionais que se chega à obrigação, não se segue que a obrigação tenha sido de ordem racional" (Bergson 1978 , p. 18). Assim como essas tendências escapam ao domínio da razão, o todo da obrigação que pressiona o homem na direção de certo tipo de conduta, assevera Bergson, nada tem a ver com as determinações do intelecto. Não é a consciência acionada por um princípio que emana da razão que constrange e impele o indivíduo a se conduzir de acordo com o dever, ou sob o lema do 'dever pelo dever'. Este papel é desempenhado justamente pelo todo da obrigação, em seu caráter social. Destarte, um imperativo será mais intensamente categórico à medida que se aproxime da natureza do instinto - uma força infra-racional -, do qual o chamado da obrigação efetivamente se aproxima, uma vez que explicita e se impõe antes que o raciocínio possa se processar e encontrar seus fundamentos. Mais precisamente, a obrigação não se constitui primeiramente como um conjunto de princípios dos quais se deduziriam máximas específicas e obrigatórias, para, posteriormente, impregnar categoricamente o comportamento dos homens. Inversamente, ela brota de um sedimento social, de um espectro de pressões que se estendem em aspirações. Essa seria a matéria da moral, cujo conteúdo e forma reaparecem transfigurados nas teorias elaboradas pelos filósofos. Bergson denuncia: "Cada um desses sistemas (de máximas) preexiste, pois, na atmosfera social à chegada do filósofo; ele compreende máximas que se aproximam suficientemente por seu conteúdo daquelas que o filósofo formulará e que são obrigatórias." (Bergson, p. 75). 
permaneça no registro da analogia. Em ambas, a regularidade se revela como pressuposto para a preservação da espécie. Como o filósofo enfatizara em seu terceiro livro, numa das linhas divergentes tecidas pelo elã, a inteligência se impõe como uma vertente distinta do instinto, sem que dele jamais se separe por completo. Em As duas fontes, veremos que ante a potencialidade geradora de representações que põe em risco a marcha da vida, o elã mostra-se perspicaz, estimulando no interior da própria inteligência a produção de recursos que a preservem de suas próprias disposições, recuperando algo da vertente com a qual, no processo evolutivo, ela originalmente se mesclava. Afinal, "As duas atividades, que a princípio se compenetravam, tiveram de se dissociar para crescer; mas qualquer coisa de cada uma continuou a aderir a outra. Outro tanto se diria também de todas as grandes manifestações da vida. Cada uma delas apresenta as mais das vezes no estado rudimentar, ou latente, ou virtual, os caracteres essenciais da maior parte das outras manifestações" (Bergson 2005, p.107). Sob esse registro, o impulso vital atua de modo que a inteligência seja permanentemente secundada por um pendor instintivo que açula nela uma neutralização dos lampejos negativos que ameaçam a espécie e minam sua potência seja para agir, seja para persistir na existência. Assim, a imperiosidade do conjunto dos hábitos, em sua totalidade orgânica, é correlata àquela do instinto nas sociedades naturais, mas é preciso frisar que a ação da natureza, no caso humano, limita-se a um tipo de determinação absolutamente indireta. Esta força jamais ultrapassará a condição virtual. O autor outra vez: "Teremos de nos dizer sempre que, não sendo obrigação alguma de natureza instintiva, o todo da obrigação teria sido instinto se as sociedades humanas não tivessem de certo modo um lastro de variabilidade e de inteligência. Trata-se de um instinto virtual, como o que jaz por trás do hábito de falar" (Bergson 1978, p. 23). A obrigação que nos coage de modo similar ao instinto permanece obra da inteligência; daí a sua virtualidade. Nesse sentido, o todo da obrigação - ou a instituição de uma 
ordem moral - constitui um dos meios pelos quais os homens permanecem ligados à vida, se considerarmos que a organização social responde a uma exigência vital.

Enfim, esta teria sido a artimanha desenvolvida pelo elã vital para minimizar as pretensões excessivas de autonomia, que, como vimos, constituem a primeira forma pela qual a inteligência obstaculiza os propósitos vitais. No entanto, ante as ameaças a sua obra e ao seu próprio movimento, as quais emanam da sua mais prestimosa realização, a vida teria operado para que outra tendência se inscrevesse na inteligência, de modo que esta desenvolvesse, a partir de si mesma, uma aptidão para engendrar explicações e sentidos em total descompasso com os critérios da razoabilidade. Destarte, ponderando que há sociedades sem filosofia, arte ou ciência, mas nenhuma sem religião, o filósofo indaga como é possível que, mesmo nas sociedades em que a razão foi elevada à condição de critério maior para conduzir a existência, seres inteligentes se deixem guiar por imagens ou ideias inequivocamente desarrazoadas ante os critérios da logicidade. Ao elucidar essa questão, sua argumentação repousa na ideia de que uma certa estrutura caracteriza o espírito humano desde tempos imemoriais até a nossa atualidade, de modo que nem mesmo a reiterada crença numa evolução inexorável nem o orgulho ocidental referente ao seu alto grau civilizatório obstruíram a manifestação das crenças mais primárias. E que estrutura seria essa? Ora, as representações engendradas para produzir superstições ou para explicar aspectos fundamentais da existência não advêm da percepção ou da lógica. Elas possuem, via de regra, uma natureza fantasmática e se originam num ato imaginante, mais propriamente numa faculdade de fabulação, constitutiva do humano. Assim, no segundo capítulo de As duas fontes, Bergson não hesita em pontuar: não é apenas a racionalidade que singulariza o homem, o pensamento absurdo também lhe é peculiar. Ou seja, ele é o único ser capaz de fundar sua existência no insensato.

De maneira similar à obrigação, sustenta Bergson, a fabu- 
lação, o imperativo de delirar, ancora-se em bases vitais, ${ }^{13}$ e se traduz na potencialidade de engendrar imagens alucinatórias amplamente variáveis. Deste talento tão singularmente humano, toda uma história de ficções, dramas, romances e mitos teria se desenvolvido. Seu intento primordial, no entanto, consistiria em produzir representações religiosas. Bergson o afirma com precisão: "É, pois, provável que poemas e fantasias de todo gênero tenham vindo por acréscimo, aproveitando-se que o espírito sabia fazer fábulas, mas que a religião era a razão de ser da função fabuladora: em relação à religião, essa faculdade seria efeito e não causa" (Bergson 2005, p. 90). Atentemos para a afirmação final. $\mathrm{O}$ ato fabulador teria se desenvolvido como um atributo humano no processo evolutivo, um traço pertinente à espécie, respondendo a necessidades inesperadas que teriam se delineado no movimento imprevisível e criador da vida. Nesse sentido, seria lícito considerar que o confronto com um determinado problema teria sido contornado pelo elã vital, o qual, em seu processo contínuo de organização, esforço e luta com a matéria resistente, teria engendrado essa atividade imagética, descortinando ao homem o caminho das representações fantásticas, as quais, por seu turno, multiplicam-se impulsionadas pela função fabuladora.

Uma potencialidade imaginante, criadora de sonhos e de representações fantásticas, plenamente insensatas aos olhos da ra-

13 Em As duas fontes, persiste o método bergsoniano, o qual implica priorizar as linhas de fato. Decorre daí que o diálogo com diversas ciências será efetivado, mais particularmente com a biologia e as humanidades. O filósofo reconhece que a religião constitui um fato social e enquanto tal constitui-se como objeto de estudo de ciências específicas. No entanto, sob a sua perspectiva, a compreensão radical desse fenômeno exige o reconhecimento de que ele possui uma origem nas necessidades da vida. Daí que a religião desponte em todas as organizações humanas, de todos os tempos, e tenha um papel crucial quanto à manutenção de seu equilíbrio. Forjadas pela inteligência, elas constituem uma função mental universal. Aspecto que, de acordo com o autor, escapa às ciências como a sociologia, a psicologia e mesmo como a história, as quais não esclarecem a persistência da religião na história da humanidade. Sob esse prima, a religião, em Bergson, “(...) responde (...) sobre o plano da inteligência humana uma necessidade vital, mas ao modo do instinto no animal a uma necessidade vital." (Worms 2011, p.312). 
zoabilidade, teria surgido como viés de elucidação, despertando a inteligência para perspectivas que, sob o prisma da faculdade lógica jamais se desvelariam. O texto é contundente:

Ora, que teria feito a natureza, depois de ter criado seres inteligentes, se tivesse querido prevenir certos perigos da atividade intelectual sem comprometer o futuro da inteligência?(...) Se, portanto, a inteligência devia ser retida, de início, num declive perigoso para o indivíduo e para a sociedade, só poderia sê-lo por constatações aparentes, por fantasmas de fatos: à falta de experiência real, era uma contrafação da experiência que se tornava necessário suscitar (Bergson 2005, p. 100).

Oriundas das imagens fictícias antinômicas às evidências experimentais, e que desrealizam a experiência - "fantasmas de fatos", para ficarmos na terminologia bergsoniana -, essas imagens traduziriam a estratégia pertinente ao movimento vital para deter a inteligência incapaz de avaliar os perigos intrínsecos a muitas de suas pretensões e de suas inclinações. "Devemos notar que a ficção, quando portadora de eficácia, é como uma alucinação nascente: é capaz de contrabalançar o juízo e o raciocínio, que são as faculdades propriamente intelectuais." (Id., Ibid.). Ora, não é pouca a ousadia com que Bergson, mais uma vez, volta-se contra a tradição. A clareza, destarte, já não habita as vias do raciocínio lógico, desde sempre tão cerebradas; inversamente, ela aflora nas vias tradicionalmente associadas ao erro, ao falso, ao equívoco, ou seja, nas sendas do delírio e da invenção de irrealidades:

Uma ficção, se a imagem for viva e obsediante, poderá precisamente imitar a percepção e, por isso, impedir ou modificar a ação. Uma experiência sistematicamente falsa, erguendo-se perante a inteligência, poderia detê-la no momento em que ela estivesse a ir longe demais nas consequências que tira da experiência verdadeira (Id., Ibid. 2005, p. 92).

É preciso frisar que, também nesse caso, é a partir da própria inteligência que o elã atuará no intuito de conter a loucura da inteligência, impedindo que ela opere a ruptura da coesão social 
ou sacrifique o propósito maior da vida, qual seja, o de prosseguir em sua marcha criadora. Por essa razão, Bergson considera que a produção dos "fantasmas de fatos" ou de "imagens alucinatórias", tal como a obrigação, vem suprir o lugar naturalmente ocupado pelo instinto em outros seres. Mais precisamente, a fabulação corresponde de fato a invenções da inteligência, mas não da inteligência pura, uma vez que algo nela deve aflorar para que se potencialize sua dimensão imaginante. Daí que a noção de instinto virtual seja novamente mobilizada. Reações instintivamente suscitadas em outros seres vivos encontrariam seu correlato nas alucinações engendradas pela inteligência nos seres dotados de vontade livre. Bergson assim se pronuncia:

(...) é preciso que uma virtualidade de instinto ou, se se preferir, o resíduo de instinto que subsiste em torno da inteligência, produza o mesmo efeito: não pode agir diretamente, mas uma vez que a inteligência trabalha sobre representações, suscitá-las-á 'imaginárias' que farão frente à representação do real e que conseguirão por intermédio da própria inteligência, contrabalançar o trabalho intelectual. Assim se explicaria a função fabuladora (Bergson 2005, p. 108).

Nesse sentido, a inteligência, açulada por tendências virtuais, legisla e controla os limites em que o desinteresse pela vida se manifesta. Ao secundá-la, tais tendências deslindam-nos o modo pelo qual a vida se manifesta em prol da perpetuidade da espécie, permitindo que, a despeito da fragilidade intrínseca à inteligência e de sua potencialidade para obstruir a ordem social, a espécie logre perseverar, e o impulso vital prossiga em sua marcha. A religião revela-se, assim, uma exigência vital que se inscreve em nós; com ela, somos estimulados a produzir imagens delirantes e a crer nelas como se fossem reais. Como assinala Lapoujade, “(...) temos virtualmente a necessidade de crer. (...) o ato de crer responde à estrutura da nossa organização biológica (...) somos naturalmente religiosos, ainda que cada uma das religiões não seja natural" (Lapoujade 2010, p. 85). 
Debrucemo-nos com mais especificidade sobre os modos pelos quais a tendência para ficcionalizar vem contraditar as representações negativas. As representações imagéticas e o conjunto de superstições que constituirão, posteriormente, a base dos sistemas religiosos, logram atenuar o desencorajamento que impregna o intelecto quando este, confrontado com o vazio, reflete lucidamente acerca de sua mortalidade. Nesse caso, um imaginário que se constitui desde sempre nos agrupamentos humanos, assumindo uma multiplicidade infindável de formas, evoca as representações de uma existência para além da morte, sugerindo a representação da vida individual como algo que não se estancaria jamais. A imagem de uma existência sem termo ameniza a depressão suscitada pela clareza acerca da mortalidade inexorável e revitaliza o desejo de viver: “(...) esta imagem, (...) lançada [pela vida] no campo da inteligência onde a ideia acaba de se instalar, repõe as coisas em ordem; a neutralização da ideia pela imagem manifesta então o próprio equilíbrio da natureza, que se impede de escorregar" (Bergson 2005, p. 117). Eis o modo pelo qual, ante a ideia de que talvez a condição humana se ancore sobre o nada, a vida vai estimular a inteligência a defender-se de si mesma. A fantasmatização religiosa vem restabelecer o equilíbrio entre o humano e o que o supera, suscitando-lhe a confiança; uma vontade debilitada encontra nela estímulos para se recompor ante a inevitabilidade da morte, e logra responder à urgência de lançar-se no mundo, seguindo o impulso dinâmico da vida. Bergson nota ainda que a instauração de deuses e de entidades religiosas atribuem ao homem um lugar no mundo, e fazem dele um ser privilegiado, objeto de cuidado e de proteção permanentes. A crença vem, destarte, contrapor-se a uma pensamento que, ao refletir acerca de sua inserção num universo desmedido, vislumbra a sua nulidade, a sua condição de ponto insignificante na imensidão, como o diria Pascal, interlocutor tácito e permanente em As duas Fontes. Ancorado nas irrealidades produzidas pelo fabular, o homem, mesmo inserto num universo regido por leis que lhe escapam, esquiva-se do seu 
desamparo, de sorte que o lugar por ele ocupado reveste-se de valor e de significação. Ou seja, as ficções, as imagens irreais de entidades protetoras e transcendentes, permitem que aquele que crê veja a si mesmo como alguém que ocupa uma centralidade para a qual deuses e entidades estão permanentemente voltados e atentos. Ao refletir sobre a crença nos espíritos, Bergson sustenta: “(...) benevolente ou malévola, uma intenção do que o rodeia segue-o por toda parte, como a lua parece correr com ele quando ele corre. Se for boa, poderá repousar sobre ela. Se lhe quiser mal, tentará desviar o seu efeito. De qualquer maneira, terá sido tomado em conta" (Bergson, p. 153). Sejamos claros: a religião permite ao homem entrever um sentido para sua existência. Não há de fato nada que estimule mais a ligação à vida do que o vislumbre de um sentido que dissocie o existir da gratuidade estéril. Por razões práticas e vitais, como observa F. Worms, o homem carece profundamente de um sentido; a religião, invenção que se efetua em âmbito racional, fornece esse sentido, ainda que, nos termos do comentador, ao preço de uma regressão metafísica: "O homem compensa os defeitos de sua inteligência não exatamente pelos instintos (em comunicação imediata com a vida, segundo a evolução criadora) mas pelas ficções!" (Worms 2011, p. 310). Sob a égide dessas construções fantasmáticas e fecundas, os seres inteligentes encontram de fato justificativas para persistir na existência, para agir no presente, antecipando o futuro, salvaguardando, enfim, o movimento do elã. Enfim, o equilíbrio perdido com o vislumbre do desamparo e da mortalidade é restabelecido por intermédio das imagens suscitadas por um instinto virtual no interior da inteligência. O remédio para conter a turbulência emerge pois no próprio homem: “(...) é a inteligência que imita o instinto social (...) Daí todo um sistema de ficções que falsifica a percepção verdadeira e que tem sua lógica interna” (Jankélévitch 1959, p. 189).

Ademais, em seu combate às disposições negativas da inteligência, as representações religiosas atenuam ainda os efeitos da 
indeterminação dos atos humanos, sempre sujeitos às desditas do acidente e do acaso. Para minimizar ou para superar os distúrbios que o imponderável desperta, a imaginação que irrompe no âmbito da inteligência engendra representações de potências ou deuses favoráveis, aptas a influenciarem as causas naturais, garantindo que os resultados das ações se conformem aos objetivos originalmente perseguidos pelo agente. Nesse sentido, Bergson alude à crença na sorte como representativa do modo pelo qual a inteligência recorre a instâncias extra-humanas, quando reconhece sua impotência ante a imprevisibilidade dos acontecimentos. Instaura-se, assim, uma "garantia extra-mecânica de sucesso", no dizer do autor, que se formaliza seja na representação de intenções e potências associadas à ideia de sorte, do acaso ou de deidades que auxiliam favoravelmente o encadeamento dos fatos, bem como a coerência entre os atos e os resultados. Sob essa perspectiva, insiste o filósofo, a irrupção vital, que ocorre por meio da função fabuladora, ao (re)encantar o mundo, torna preponderante uma perspectiva otimista e reage contra o esmorecimento da inteligência ante o indeterminado que impregna seus propósitos. Restitui-se, pois, a confiança necessária para que o agente persevere em seus atos, a despeito do espectro da imprevisibilidade e do fracasso que o assedia.

À medida que a constituição de deidades atua como transcendência punitiva para os excessos, reforçando inclusive o ideário comum ao grupo, podemos considerar que as fabulações religiosas, tal como as obrigações, também reforçam a integração, contendo simultaneamente as veleidades dissolventes e a arrogância do intelecto. ${ }^{14}$ Mas elas vêm, sobretudo, compensar o caráter de-

14 É importante observar que, sob a perspectiva desta filosofia, moral e religião, em sua fecundidade, pautam-se por finalidades similares, mas isso não significa que elas se equivalham. Mesmo considerando-se que a moral resulta de uma necessidade fixada pela vida e que ela não se circunscreve a deliberações racionais, seu recurso primordial residirá em preceitos abstratos que coagem os indivíduos à obediência e à disciplina. No âmbito religioso, as criações fantásticas e imaginárias engendradas 
pressivo do pensar, e propiciam um 'suplemento de força”, mantendo, assim, a imprescindível conexão entre os seres pensantes e a vida: "Essa reação suscita, no interior da própria inteligência, imagens e ideias que põem em xeque a representação deprimente, ou que a impedem de se atualizar. (...) crença significa, portanto, essencialmente, confiança (...)” (Bergson 2005, p. 134). Destarte, o delírio e o sonho já não vêm nos divorciar do ímpeto vital, obscurecendo a atenção com que a inteligência deve se mover no mundo; inversamente, eles incutem em nós o apego a ela e acenam com a supressão do desamparo visceral que assedia a condição humana.

De fato, essas ficções, obras da inteligência insufladas por um instinto virtual, conjuram as angústias que assediam o "homem normal". Elas atualizam uma tendência imanente ao elã e materializam-se sobretudo e primeiramente em formas de religiosidade, de sorte que ganha vulto a asserção bergsoniana: "A verdade é que a religião, sendo coextensiva à nossa espécie, deve estar ligada à nossa estrutura" (Id., Ibid., p. 53). Estrutura que faz de nós seres aptos a fantasmatizar. A imperiosidade de imaginar e criar representações delirantes constituiria pois uma resistência que a vida inscreve em nossa natureza, contra as patologias imanentes à inteligência, atrelando-nos mais fortemente à existência. Bergson assevera: "A religião é o que deve preencher, em seres dotados de reflexão, um deficit eventual do apego à vida" (Id., Ibid. 2005, p. 180). Nesse sentido, pondera Worms, a religião ultrapassa o condicionamento e os hábitos, ela põe a imaginação a serviço da preservação da espécie. Bergson é incisivo: "A religião estática apega o homem à vida e, por conseguinte, o indivíduo à

pela função fabuladora visam também o fortalecimento da disciplina, da unidade e incrementam a solidariedade; no entanto, o modo pelo qual esses fins são alcançados difere daquele pertinente à obrigação. Não é originalmente com a instituição de normas ou preceitos abstratos, mas com a proliferação de imagens, de representações irreais e absurdas, no contracampo da lógica e de seus princípios, que esse objetivos são alcançados. Cf. Bergson 2005, p. 174. 
sociedade, contando-lhe histórias comparáveis àquelas com que se embalam as crianças" (Bergson, p. 180).

\section{Da clausura humana ao salto para a vida}

Em sua última obra, Bergson postulará a sociabilidade, a moral e a religião não apenas como as estratégias desenvolvidas pela vida para conter os obstáculos intrínsecos à inteligência, mas também como as esferas essenciais em que a vida humana se circunscreve e constrói sua existência. Como assinala D. Lapoujade, são as atividades ligadas à técnica, à ciência e à religião que proliferam nessas instâncias. Mais precisamente, nesses círculos encerrados em si mesmos, cujos contornos são permanentemente ratificados, a humanidade tece sua história, constrói sua obra. (Lapoujade 2010 p. 89).

Não obstante, circunscrita a essas esferas delineadas pelas tendências vitais, a humanidade permanece atrelada a formas estacionárias, que, a despeito da indeterminação que rege a vida inteligente, se repetirão infindavelmente no seio de uma coletividade, opondo-se às formas instituídas por outros grupos. Constatando a persistência dessa tendência nos agrupamentos humanos, Bergson considera que toda sociedade, qualquer que seja o seu grau de desenvolvimento se organiza enquanto sociedade fechada. Nesse sentido, toda sociedade erige-se no interior de contornos estritos, visto que sua unidade não se consuma sem o pressuposto da exclusão, base sobre a qual advêm a intolerância e a violência contra aqueles cuja existência põe em xeque tal unidade. Explicita-se, pois, que a moral fechada e a religião estática produzidas nestas esferas, a despeito de suas diferenças, vêm consumar, numa invenção inexaurível de formas, as disposições preventivas inscritas no elã para apaziguar a negatividade que aflora na intimidade dos seres pensantes, garantindo assim que a espécie possa superar o obstáculo maior com o qual ela se depara, qual seja: ela mesma. Mas será no interior desses círculos fechados que estas instâncias 
lograrão fecundar e perpetuar os laços que atrelam o homem à vida. Isso significa que, por mais que a inteligência acene com caminhos indefinidos para o movimento vital, a sobrevivência da espécie impõe um certo alentecimento, uma vez que se torna necessário padronizar formas de existência como aquelas que se cristalizam por todas as dimensões da sociedade e da vida em geral. Evidentemente, no âmbito dessas esferas em que a humanidade tece sua história, há progresso, desenvolvimento, invenção, transformação. Todas essa amplitude não implica, contudo, prerrogativas de superação dos limites fixados pela natureza. E o mundo humano, a despeito de sua inesgotável fecundidade, revelar-se-á também como uma forma de clausura, tal como aqueles constituídos por outros seres e dos quais o elã deve se desviar para dar continuidade à vida. ${ }^{15}$ Sob esse prisma, o privilégio do homem, de fato, é nenhum. Deleuze assim se pronuncia:

(...) o homem gira em círculo em sua sociedade tanto quanto as espécies em torno de si mesmas ou as formigas em seu domínio. Nada, aqui, parece conferir ao homem a abertura excepcional anunciada precedentemente, como o poder de ultrapassar seu plano e sua condição (Deleuze 1999, p. 89).

15 No seu processo de invenção, o ímpeto vital gera formas inusitadas e surpreendentes. Essas mesmas formas, no entanto, findam por enclausurar esse impulso obstinado e parecem esterilizar sua potência inventiva. O peso da materialidade se faz sentir mesmo quando a liberdade se amplia, de modo que a tensão criadora do elã atenua-se ou paralisa, circunscrevendo-se à perpetuação de indivíduos e de espécies pautadas por estruturas repetitivas que parecem ter atingido um ápice, um ponto além do qual a liberdade não se lançará. Daí o antagonismo entre o ato instaurador de uma nova realidade e o ato que se fecha na forma criada, como evidencia o autor em A consciência e a vida: "A vida em geral é a própria mobilidade; as manifestações particulares da vida só aceitam essa mobilidade a contragosto e estão constantemente atrasadas com relação a ela. (...)" (Bergson 2011, p. 122). Notemos, contudo, que se a marcha para frente do elã se alentece em formas que se cristalizam, esse ímpeto não titubeia em contorná-las, de modo que outras formas advêm. A vida logra, pois, a continuidade de seu processo criador desviando-se das estabilidades em que as espécies teimam em se confinar. 
Ora, se a vida humana se fecha em círculos e se não logra ultrapassar sua condição, como o afirma Deleuze, a nós, resta interrogar: essas estratégias desenvolvidas pelo elã vital, com o intuito de domar e curar a ferida da negatividade que dimana no cerne da inteligência - a obra maior da vida -, lograriam, ao menos, erradicá-la? Conquanto a vida seja bem sucedida em seu intento de conter a negatividade, impedindo que ela se estabeleça enquanto tônica prevalecente, o que chancelaria o fim do humano, afirmar que as disposições vitais de fato suprimem tais ameaças seria já um exagero. Se assim o fosse, não testemunharíamos as constantes e inexauríveis manifestações de destruição e de negatividade na história, na vida social, em nosso cotidiano e, sobretudo, em nossa própria interioridade. Decerto, em virtude da atualização das tendências vitais, como sustenta Lapoujade, torna-se possível a coexistência com a negatividade e com os riscos aos quais a inteligência submete o empreendimento do ímpeto vital, mas no âmbito das esferas fechadas não há possibilidade alguma de que a inteligência, a partir de si mesma ou de instintos virtuais, possa emancipar-se de seus males ou transmudar radicalmente seu modus operandi, do qual, afinal, emanam as suas agruras mais atrozes. Dito de outro modo, com a moral e com a religião, tal como elas se delineiam no interior de círculos fechados, os homens constroem sua história, logram domesticar suas angústias psíquicas, controlar sua doença, mas eles não saltam para além dos contornos do círculo em que a espécie se enreda ao viver num mundo de representações. Não logram, pois, vencer sua visceral disposição para a negatividade. ${ }^{16}$ Sob esse aspecto, aludindo ainda

16 "Este equilíbrio apenas proporciona compensações, quer dizer, consolações que caracterizam a doença da qual ele não pode sair, sua nevrose. E, sem dúvida esta nevrose é capaz de se aproximar da psicose. Bergson não diz, com efeito, que a sociedade vive num tipo de sonho, de pesadelo permanente? (...) A espécie humana é uma nevrose da vida, ela é a vida neurotizada. Eis o diagnóstico de As duas fontes. Sabe-se desde Matéria e Memória que o homem é virtualmente psicótico. Mas em As duas fontes ele é atualmente, especificamente, efetivamente, neurótico, como o testemunham suas fabulações destinadas a consolar suas 'representações do real', e 
à preciosa análise de Lapoujade, a espécie humana se constitui como uma nevrose da vida. Uma espécie doente. O comentador, ainda uma vez: "Enquanto o homem vive no interior dos círculos, ele pode de fato alargá-los, mas ele não pode quebrá-los. Ele não pode se elevar acima de sua inteligência nem saltar por cima dele mesmo para alcançar o super-homem ou a super-humanidade" (Lapoujade 2010, p. 88).

Ademais, uma outra questão se coloca. Estivemos até o momento problematizando o fato de que obstáculos inesperados findam por se delinear e que, no intuito de contê-los, as tendências vitais se atualizam, fixando as instâncias em que a vida social e humana se desenrola. Ou seja, o ímpeto vital finda por se enrijecer também no âmbito da interioridade humana, tal como nas formas fechadas e repetitivas geradas pela natureza. A princípio, seria lícito entrever aqui uma profunda contradição. Se a vertente da vida que conduz ao homem é a única a romper os grilhões de modo que o elã possa perseguir a criação em sua radicalidade e dar continuidade ao avanço da vida, se o homem constitui a via em que a duração mais se expande atingindo os mais elevados graus de liberdade, tal como afirmara Bergson em A evolução Criadora, o fechamento desses círculos, nos quais a sociedade e a história humanas proliferam e nos quais culmina a natureza, não restituiriam esses grilhões? A humanidade viveria em universos estáticos, sem privilégio que a diferencie radicalmente das outras espécies, como pondera Deleuze, e incapaz de liberar-se do niilismo que impregna sua condição?

O pensamento bergsoniano se ateria a esse impasse se o filósofo não tivesse interrogado verticalmente o modo pelo qual a inteligência, radicalizando a flexibilidade com que a vida a contempla, logra ir além das intenções vitais e ultrapassa os obstáculos 
que ela própria opõe ao ímpeto da vida. Ratifiquemos: atendo-se à sua condição de ser inteligente, o homem não ultrapassa a sua doença; ele se atém a uma ligação indireta com a vida, seja por intermédio da sociedade ou de entidades fictícias. No entanto, a flexibilidade da inteligência vai além do que fora pretendido pela natureza. Com um esforço visceral, ela pode lançar-se para além dos círculos, superar o divórcio com a criação, bem como a sua natureza deprimente. Para isso, será preciso o também doloroso e radical mergulho na experiência da abertura, a qual, se suscitada por uma emoção supraintelecutal e por um amor metafísico, vivifica as formas fixas do pensar e opera uma conversão nos modos de agir. Este seria o viés do esforço criador pelo qual os vínculos entre o homem e a vida tornam-se plenos, e o elã logra superar a negatividade intrínseca à inteligência, perpetuando sua inserção no futuro. Assim se descortina a fenda pela qual se torna plausível o salto para além da condição humana, tal como fixada pela natureza, no qual os círculos fechados são ultrapassados. A possibilidade da coincidência com o dinamismo criador da vida torna plausível aos seres inteligentes romperem o universo estático de suas representações e seguir o impulso do elã em toda a sua potencialidade. O salto aqui é aquele que vai do finito ao infinito. Nesse caso, não mais o vazio; não mais o nada; a alegria é que impera. Encontramo-nos, então, para além da inteligência, dos instintos virtuais, para além da natureza e de todo niilismo. Dimensões alcançadas apenas pelos indivíduos extraordinários, os místicos. Sozinhos eles superam a espécie e vitalizam a história. Capazes de contagiar as almas alheias, mobilizam-nas para o contato com o movimento vital. Esse processo não muda a condição dos homens; não lhes cessa a patologia. A existência de todos eles será ainda vivenciada no interior dos círculos, assediada pelo espectro da negatividade, mas algo do aberto nela vem se encravar, dinamizando-a. Essas proposições nos colocam já na vertente de uma nova discussão.

Nesse artigo, almejávamos pontuar, primeiramente, que os brevíssimos argumentos bergsonianos tecidos em $\mathrm{O}$ pensamento 
e o Movente, antes mencionados, e interpretados tanto por Bento Prado quanto por Jankélévitch como indícios de um pensamento norteado pela alegria, reconfiguram-se em As duas fontes, momento em que novas direções serão tecidas pela fecundidade vertiginosa dessa filosofia. Em seguida pretendíamos frisar que, nesse deslocamento, uma novidade incontestável sobrevém: não haverá mais garantias para esse horizonte alegre. Doravante, a negatividade assombra ancorada em bases ontológicas, não mais como fantasma.

\section{Bibliografia}

BERGSON, H. O pensamento e o Movente. São Paulo: Martins Fontes, 2006.

A evolução criadora. São Paulo: Martins Fontes, 2005

As duas fontes...(1) Rio de Janeiro: Zahar Editores, 1978 .

As duas fontes....(2) Coimbra: Ed. Almedina, 2005. Memória e vida. São Paulo: Martins Fontes, 2011. Matéria e Memória. São Paulo: Martins Fontes, 1990.

"A consciência e a vida", In: A energia espiritual.

São Paulo: Martins Fontes, 2009.

CAYMEX, F. «La societé sortie des mains de la nature », WORMS, F. (org.), Annales bergsoniennes V. Paris: PUF, 2012.

DELEUZE, J. O Bergsonismo. São Paulo: Ed. 34, 1999.

FRANÇOIS, A. Bergson, Schopenhauer, Nietzsche. Paris : PUF, 2008.

GOUHIER, H. Le Christ des Evangiles. Paris: Arthéme Fayard, 1961. 
JANKÉLÉVITCH, V. Henri Bergson. Paris: PUF, 1959.

LAPOUJADE, D. Puissances du temps. Lonrai: Les Éditions de Minuit, 2010.

LEOPOLDO E SILVA, F. Intuição e discurso filosófico. São Paulo: Loyola, 1994 .

PRADO JR. Bento. Presença e campo transcendental. Consciência e negatividade na filosofia de Bergson. São Paulo: Edusp, 1989.

RIQUIER, C. Archéologie de Bergson, Archéolologie de Bergsontemps et métaphysique. Paris: PUF, 2009.

WORMS, F. Qual vitalismo para além de qual niilismo? In: PINTO, D.C. M; MARQUES, S. T. (Orgs.). Henri Bergson Crítica do negativo e pensamento em duração. São Paulo: Ed. Alameda, 2009.

WORMS, F. Bergson ou os dois sentidos da vida. São Paulo: Editora Unifesp, 2011. 